\title{
Generation of Microsecond Ytterbium-Doped Fibre Laser Pulses using Bismuth Telluride Thin Film as Saturable Absorber
}

(Penjanaan Denyutan Laser Gentian Mikrosaat Iterbium-Terdop yang Menggunakan Filem Nipis Telurida Bismut sebagai Penyerap Boleh Tepu)

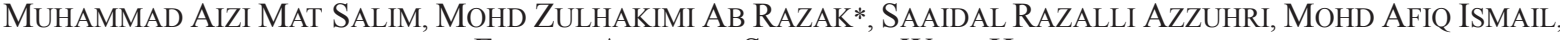 \\ FAUZAN AHMAD \& SULAIMAN WADI HARUN
}

\begin{abstract}
Bismuth telluride $\left(B i_{2} \mathrm{Te}_{3}\right)$, a type of topological insulators, is currently in hot pursuit due to its unique physical properties. Therefore, this paper describes a simple Q-switched Ytterbium-doped fiber laser (YDFL) by using Bi, Te ${ }_{3}$ thin-film as saturable absorber. The few layers Bi Te film was fabricated using optical deposition technique and subsequently, was used in an all-fiber, YDFL setup. As a result, a self-starting $Q$-switching pulses were first occurred when the laser pumping power reached $88.6 \mathrm{~mW}$. As the pump power level increased, the observed pulses repetition rates had increased steadily from 17 to $29.63 \mathrm{kHz}$. Hence, this work demonstrated that Bi,Te thin-film can be used to successfully generate Q-switching pulses at 1-micron region and is well suited for many photonic applications operated at this wavelength region.
\end{abstract}

Keywords: Bi, Te 3 ; optical deposition; Q-switched; saturable absorber; ytterbium fiber laser

\section{ABSTRAK}

Telurida Bismut (Bi, $\left.\mathrm{Te}_{3}\right)$, sejenis penebat bertopologi adalah sejenis bahan yang menjadi tumpuan kajian pada masa ini kerana keunikan sifat bahannya. Justeru, kertas ini menerangkan tentang kaedah mudah untuk menghasilkan denyutan laser rangkaian-Q berasaskan gentian optik iterbium (YDFL) dengan menggunakan filem nipis Bi ${ }_{2}$ e $_{3}$ sebagai penyerap boleh tepu. Beberapa lapisan filem nipis Bi, Te telah dihasilkan dengan menggunakan kaedah pemendapan optik dan seterusnya digunakan dalam satu persediaan penghasilan denyutan laser YDFL dengan hanya menggunakan komponen gentian optik sahaja. Hasilnya, denyutan laser rangkaian-Q yang mula kelihatan apabila kuasa pengepam mencapai $88.6 \mathrm{~mW}$. Kadar pengulangan denyutan laser didapati meningkat dengan berterusan daripada $17 \mathrm{kepada} 29.63 \mathrm{kHz}$ apabila tahap kuasa pengepam dinaikkan sedikit demi sedikit. Sebagai kesimpulan, hasil kajian ini telah menunjukkan bahawa filem nipis Bi, Te ${ }_{3}$ dengan jayanya telah dapat menjana denyutan laser rangkaian-Q pada rantau 1-mikron dan keputusan ini telah membuka peluang dan sesuai digunakan dalam banyak aplikasi fotonik yang beroperasi pada panjang gelombang ini.

Kata kunci: $B i_{2} T_{3}$; laser gentian optik iterbium; pemendapan optik; penyerap boleh tepu; rangkaian-Q

\section{INTRODUCTION}

Passively Q-switching pulsed laser has attracted remarkable attention lately due to widespread and useful photonics applications in the area of material processing, optical imaging and high-speed communications. The generation of Q-switched pulsed laser by incorporating few layers of saturable absorber (SA) into a ring laser cavity is a well-known method due to its simple technique, low development cost, and flexibility (Ahmad et al. 2016). The saturable absorber or 'Q-switcher' (Bao et al. 2009; Keller et al. 1996) plays an important role to generate stable Q-switching optical pulses, including high power pulses generation (Razak et al. 2016). In recent years, carbon-based materials, for example carbon nanotube (CNT) and graphene thin films, have been widely used as SAs in order to generate optical pulses. In fact, CNT (Salim et al. 2018) and graphene (Bao et al. 2009) were found to give significantly improved results compared to the SA that is based on semiconductor saturable absorber mirror (SESAM) (Keller et al. 1996). SESAM has been the most widely used SA for few decades. However, SESAM is expensive, requires complex fabrication process, and prone to damage due to its Q-switching instabilities. The use of CNT, on the other hand, has been limited by a complex bandgap control, which prevent saturable absorption to occur at certain wavelength (Bao et al. 2009). Meanwhile, graphene has a relatively small optical absorption and low modulation depth (Bao et al. 2009). Therefore, extensive research work has been conducted to seek for new materials with efficient and effective performances as SA and possesses the following ideal characteristics: Low-cost fabrication process, wavelength-independent, large modulation depth, and high threshold damage.

Recently, topological insulators (TIs) (Bernard et al. 2012) have emerged as new alternatives SAs. TI SA such 
as bismuth selenide $\left(\mathrm{Bi}_{2} \mathrm{Se}_{3}\right.$ ) (Ahmad et al. 2015; Zhao et al. 2012) and bismuth telluride $\left(\mathrm{Bi}_{2} \mathrm{Te}_{3}\right)$ (Pinghua et al. 2013), have been extensively investigated for their performance in generating mode-locked and Q-switched pulses. Bismuth telluride is a new type of quantum electronic material, which behaves as a metal at the outer surface but in contrast, behaves as insulator at the inner layer (Chen et al. 2009; Zhang et al. 2009). The $\mathrm{Bi}_{2} \mathrm{Se}_{3}$ with $0.2-0.3 \mathrm{eV}$ non-trivial energy gap, indicates a saturable absorption effect at shorter wavelength than $4.1 \mu \mathrm{m}(0.3 \mathrm{eV})$ (Zhang et al. 2009). These materials obey Pauli's blocking principle (Zitter 1969), which stated that two or more identical fermions cannot occupy the same quantum state. The improvements of TIs have been demonstrated successfully through various publications in recent years. TIs have recorded as much as $98 \%$ of modulation depth, as reported by Zhao et al. (2012), which makes them practical and reliable SAs. Moreover, Luo et al. (2013) reported that TIs does have broadband absorption. Furthermore, TIs have added advantages in terms of simple fabrication process, low development cost, low saturation intensity, and broad effective bandwidth. Recently, researchers discovered that the nonlinear absorption property of $\mathrm{Bi}_{2} \mathrm{Te}_{3}$ could become transparent under strong illumination effect (Bernard et al. 2012). The operation of the $\mathrm{Bi}_{2} \mathrm{Te}_{3}$ based SAs have been extensively proposed in erbium doped fiber lasers (EDFL) for Q-switching operation (Chen at al. 2014; Harun et al. 2017; Li et al 2014; Luo et al. 2013). However, there are only few reports available for Q-switching operation at 1 micron region utilizing the $\mathrm{Bi}_{2} \mathrm{Te}_{3}$ based SA (Lee et al. 2014). Therefore, due to this limitation, this work is focused in bridging this research gap. The optical deposition technique that was used to fabricate SAs has been demonstrated through various work such as by using graphene oxide (Ahmad et al. 2012), single wall CNT (Mohamed et al. 2017), graphene (Luo et al. 2012) and $\mathrm{Bi}_{2} \mathrm{Te}_{3}$ (Chen et al. 2014). However, those work focus at wavelength of $1550 \mathrm{~nm}$, using erbium fiber laser, which are different from the $1-\mu \mathrm{m}$ region. Passive Q-switched ytterbium fiber lasers using $\mathrm{Bi}_{2} \mathrm{Te}_{3}$ have also been reported, such as in our previous work (Salim et al. 2017). It generated dual-wavelength Q-switched laser pulses by using photonics crystal fiber ( $\mathrm{PCF}$ ). Other works in this aspect used mechanical exfoliation method (Lee at al. 2014) and facile solvothermal method (Sun et al. 2015). Recently, there have been research work that uses $\mathrm{Bi}_{2} \mathrm{Te}_{3}$ thin flim to generate Q-switching pulses. However, in these work, high pump power (over $1 \mathrm{~W}$ ) was used and mainly suits for high power application.

In this report, we demonstrate optical deposition technique to fabricate $\mathrm{Bi}_{2} \mathrm{Te}_{3} \mathrm{SA}$ for a single wavelength Qswitched Ytterbium-doped fiber laser. The SA was sandwiched between two fiber ferrules, consequently, realizing an all-optical fiber setup. The resultant optical spectrums, pulse durations, repetition rates as well as pulse energies were recorded as pump power were increased.

\section{EXPERIMENTAL SETUP}

The optical deposition method (Kashiwagi et al. 2009; Martinez et al. 2010) was employed to create few-layer $\mathrm{Bi}_{2} \mathrm{Te}_{3} \mathrm{SA}$ by inserting the suspended fiber ferrule inside the $\mathrm{Bi}_{2} \mathrm{Te}_{3}$ solution, as given in Figure 1(a). A laser diode with center wavelength of $974 \mathrm{~nm}$ was emitted at the other side of the fiber ferrule with an output power of $108.1 \mathrm{~mW}$. The fiber ferrule was immersed in a $\mathrm{Bi}_{2} \mathrm{Te}_{3}$ solution for 30 $\min$. The ferrule was then, dried in an oven for $3 \mathrm{~h}$ at $90^{\circ} \mathrm{C}$ to remove all the excess moisture. The image in Figure 1(b) shows that few layers of $\mathrm{Bi}_{2} \mathrm{Te}_{3}$ was successfully formed on the surface of the fiber-ferrule facet after drying. Subsequently, the fabricated saturable absorber was incorporated in the laser ring cavity setup. The presence of $\mathrm{Bi}_{2} \mathrm{Te}_{3}$ in the thin-film was proved by Raman spectrum result, as illustrated in Figure 1(c). This result is similar with the findings and analysis of $\mathrm{Bi}_{2} \mathrm{Te}_{3}$ thin-film that was discussed in detailed by Russo et al. (2008).

The nonlinear absorption characteristic of $\mathrm{Bi}_{2} \mathrm{Te}_{3}$ SA was determined using dual-detector measurement system as in Kashiwagi et al. (2009). The pulse seed is a 'homemade' passively mode-locked pulses with repetition rate of $27.6 \mathrm{MHz}$ and pulse width of $0.51 \mathrm{ps}$. The output power from the laser can reach up to $20 \mathrm{~mW}$. Later, the relation between intensities and optical absorption are associated by the following equation:

$$
\alpha=\frac{\Delta \alpha}{\left(1+\frac{I}{I_{\text {sat }}}\right)}+\alpha_{\text {linear }}
$$

where $\Delta \alpha, \alpha_{\text {linear }}$ and $I_{\text {sat }}$, correspond to the modulation depth, non-saturation loss and saturable optical intensity, respectively. When plotted, the result of $\mathrm{Bi}_{2} \mathrm{Te}_{3}$ nonlinear absorption is shown as in Figure 1(d), with saturable intensity and modulation depth values of $\sim 4.5 \mathrm{Mw} / \mathrm{cm}^{2}$ and $63 \%$, respectively.

The fiber laser setup to generate Q-switched pulses using bismuth telluride YDFL is depicted in Figure 2(a). This setup comprised of a laser diode model LC96A74P20R (Oclaro) with the central wavelength of $974 \mathrm{~nm}$. The laser diode was connected to the input port of a 980/1060 $\mathrm{nm}$ wavelength division multiplexer (WDM). The common port of the WDM was connected to a $70 \mathrm{~cm}$ ytterbium doped fiber (YDF) (DF1100 Fibercore). Then the YDF was attached to the polarization insensitive isolator to ensure unidirectional propagation of light and to prevent back scattering reflection. The output of the isolator was then attached to a polarization controller (PC) that manage the polarization state of light by tuning the PC's waveplates. Then, the other end of the PC is connected to the fabricated $\mathrm{Bi}_{2} \mathrm{Te}_{3} \mathrm{SA}$, which was placed between two fiber ferrules. Then the other end of the ferrule was then linked to an input of $90 / 10$ optical coupler (OC), referred as OC1. The $90 \%$ output port of $\mathrm{OC} 1$ is connected to the reflection port of the WDM to complete the loop. Meanwhile, the $10 \%$ output port of the optical coupler was connected to the $3 \mathrm{~dB}$ optical fiber coupler, which is referred as OC2. The OC2 was used 


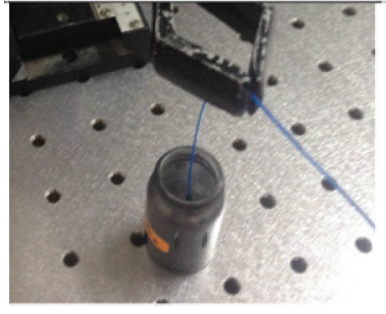

(a)

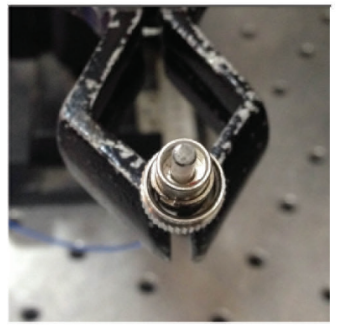

(b)

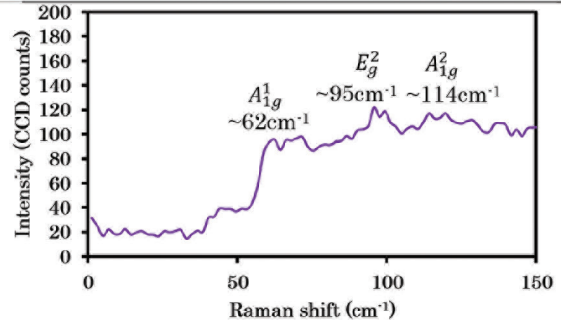

(c)

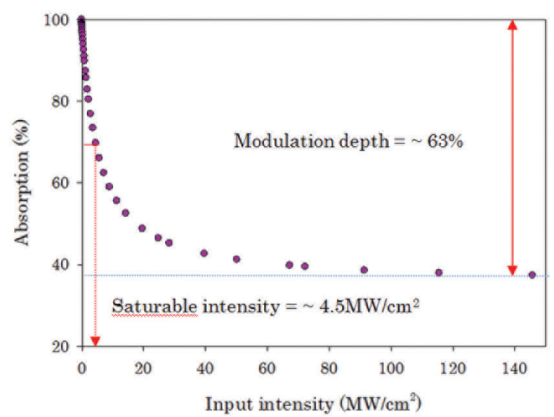

(d)

FIGURE 1. (a) The optical deposition of $\mathrm{Bi}_{2} \mathrm{Te}_{3}$, (b) a few-layer of $\mathrm{Bi}_{2} \mathrm{Te}_{3}$, and (c) nonlinear saturable absorber characteristics of $\mathrm{Bi}_{2} \mathrm{Te}_{3} \mathrm{SA}$

to measure two results simultaneously using two different types of instruments; YOKOGAWA optical spectrum analyzer (OSA) - model AQ6373 - with a $0.02 \mathrm{~nm}$ resolution, and Thorlabs's photodetector - model D400FC - connected to a YOKOGAWA oscilloscope (model DLM2054). In addition, a radio frequency spectrum analyzer and an optical power meter were also used in this experiment to monitor the results.

\section{RESULTS AND DISCUSSION}

The Q-switched first appeared at the pumping power level of $88.6 \mathrm{~mW}$. The signal was optimized by finely tuning the PC waveplates. The pulses were monitored by using a digital oscilloscope. Like other typical Q-switching pulses, the pulse width and the repetition rate are dependent on the pump power. The repetition rate has increased as the pump power levels increased while in contrast, the pulse duration has decreased during this increment in pumping power levels. Moreover, by increasing the pumping power to 95.2, 102.0, and 108.1 $\mathrm{mW}$, respectively, stable pulses with various repetition rates were recorded, as depict in Figure 2(b), 2(c) and 2(d). These show that the outputs performed according to the behavior of a Qswitched laser.

The behavior of Q-switching at $111.3 \mathrm{~mW}$ pump power was recorded as depict in Figure 3. The repetition rate of $29.63 \mathrm{kHz}$ and the pulse duration of $31.20 \mu \mathrm{s}$ were obtained from the oscilloscope traces, as illustrated in Figure 3(a). In addition, Figure 3(b) shows the full width at half maximum (FWHM) of pulse width was measured as $14.54 \mu \mathrm{s}$. The result of the repetition rate obtained from the oscilloscope was verified by comparing the output spectrum recorded by the radio frequency analyzer (RFSA) with the fundamental frequency of $29.63 \mathrm{kHz}$, as shown in Figure 3(c). The inset in Figure 3(c) shows the peak-to-pedestal ratio of $42 \mathrm{~dB}$. In Figure 3(d), an optical spectrum with lasing at $1070.08 \mathrm{~nm}$ and with output power of $10.42 \mathrm{dBm}$, was observed by using OSA.

The behavior of the pulse width and the repetition rate with different pump power levels were plotted in Figure 4(a). Due to the gain compression of the Qswitched fiber laser (Herda et al. 2008), the pulse width reduces with the increment of the pumping power. Shorter pulse width can also be obtain using shorter cavity length and by optimizing cavity loss (Herda et al. 2008; Zayhowski et al. 1991). The difference in pulse width indicates linear correlation with pump power and the curve was at the same as graphene trajectory reported by Liu et al. (2011) and Zhang et al. (2012). The minimum pulse width was measured as $14.54 \mu$ s when pump power was at $111.3 \mathrm{~mW}$. The pulse repetition rate was observed from 17 to $29.63 \mathrm{kHz}$. Meanwhile, Figure 4(b) shows the impact of varying the pump power on the performance of the average output power and the pulse energy. In this experiment, the highest pulse energy of $3.37 \mathrm{~nJ}$ was recorded at the pump power of $111.30 \mathrm{~mW}$. As reported by Martinez et al. (2010), by incorporating a high gain fiber such as double-cladded fiber, maximum pulse energy could be facilitated. Furthermore, to optimize the pulse generation significantly, an improved cavity design in terms of connection -minimizing the connection insertion losses - and an optimized cavity length, as well as higher pump power could also be considered. 


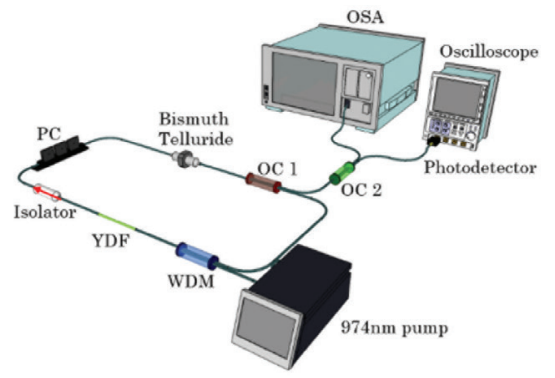

(a)

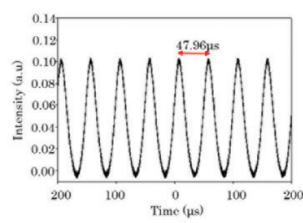

(b)

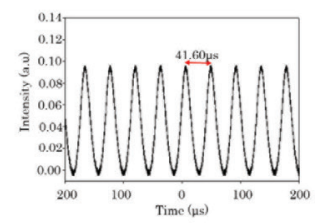

(c)

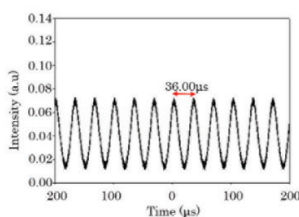

(d)

FIGURE 2. (a) The Q-switched ytterbium fiber laser setup, with pulse train corresponding to (b) $95.2 \mathrm{~mW}$, (c) $102.0 \mathrm{~mW}$ and (d) $108.1 \mathrm{~mW}$ pump power with repetition rate of $19.84,23.24$ and $27.85 \mathrm{kHz}$, respectively

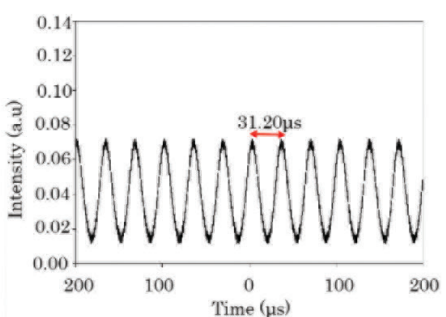

(a)

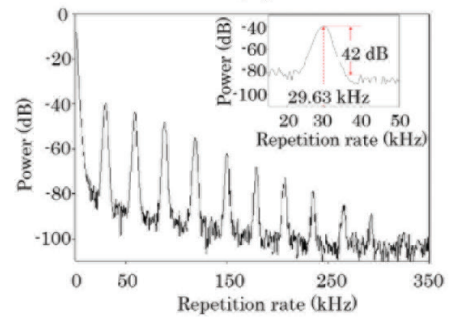

(c)

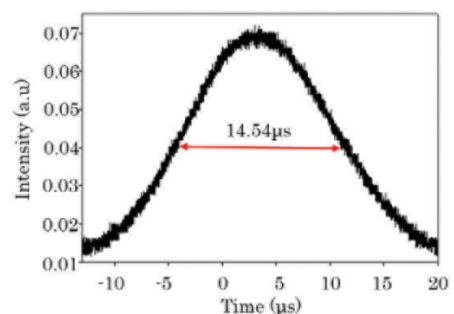

(b)

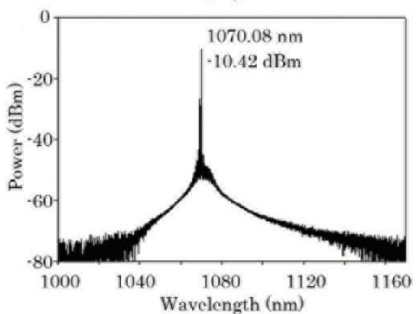

(d)

FIGURE 3. (a) The pulse train Q-switched with (b) pulse width of $14.54 \mu \mathrm{s}$, (c) frequency spectrum and (d) centered optical wavelength at $111.3 \mathrm{~mW}$ pump power and $29.63 \mathrm{kHz}$ repetition rate

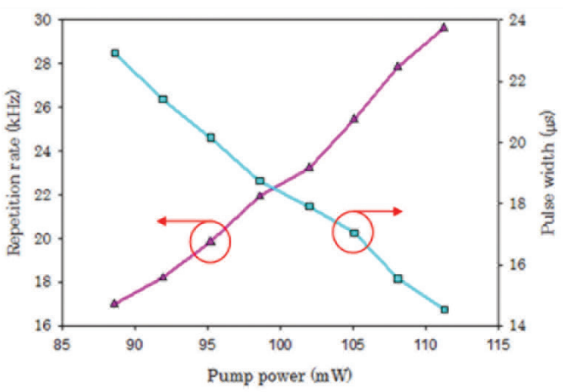

(a)

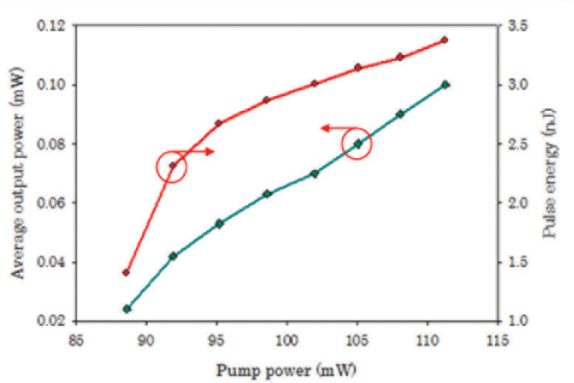

(b)

FIGURE 4. The relationship between (a) repetition rate and pulse width, and (b) pulse energy and average output power corresponding to pump power 
TABLE 1. Comparison of Q-switching results of $\mathrm{Bi}_{2} \mathrm{Te}_{3} \mathrm{SA}$ fiber laser pulses

\begin{tabular}{|c|c|c|c|c|}
\hline Reference & $\begin{array}{l}\text { Wavelength } \\
(\mu \mathrm{m})\end{array}$ & Type of SA & $\begin{array}{l}\text { Laser Pump Power } \\
\qquad(\mathrm{mW})\end{array}$ & $\begin{array}{l}\text { Pulse Repetition } \\
\text { Rates (Max.) }\end{array}$ \\
\hline Luo et al. (2013) & 1 & thin film, liquid-phase exfoliation method & 106.2 & $29.1 \mathrm{kHz}$ \\
\hline Lee et al. (2014) & 1 & Bulk-structured, mechanical exfoliation method & 204 & $77 \mathrm{kHz}$ \\
\hline Li et al. (2014) & 1 & $\begin{array}{l}\text { Bi2Te3 saturable absorber mirror, hydrothermal / } \\
\text { exfoliation method }\end{array}$ & 5270 & $151.5 \mathrm{kHz}$ \\
\hline Sun et al. (2015) & 1 & Thin film, Facile solvothermal method & 5400 & $114 \mathrm{kHz}$ \\
\hline Salim et al. (2017) & 1 & Thin film, cryogenic grinding method & 154 & $15.63 \mathrm{kHz}$ \\
\hline Gao et al. (2018) & 2 & Thin film, liquid phase synthesis method & 2220 & $57.7 \mathrm{kHz}$ \\
\hline Lin et al. (2018) & 1 & $\begin{array}{l}\text { Deposit on quartz substrate, mechanically exfoliated } \\
\text { first and then processed by hydrothermal exfoliation }\end{array}$ & 3500 & $80 \mathrm{kHz}$ \\
\hline Yang et al. (2018) & 1 & Thin film, commercial & 12200 & $630 \mathrm{kHz}$ \\
\hline This work & 1 & Thin film, optical deposition method & 111 & $30 \mathrm{kHz}$ \\
\hline
\end{tabular}

As a comparison, the results of previous wok and this work is tabulated in Table I. Although repetition rate over $50 \mathrm{kHz}$ were achieved (Gao et al. 2018; Lee et al. 2014; Li et al. 2014; Lin et al. 2018; Sun et al. 2015; Yang et al. 2018), these work require higher pumping power. This work also produces better results than our previous work (Salim et al. 2017) that uses more complex process of implementing the SA. While the work by Luo et al. (2013) shows nearly similar result, the optical deposition method that was used in this work is simple and very low cost.

\section{CONCLUSION}

This work has successfully demonstrated the use of few-layer bismuth telluride $\left(\mathrm{Bi}_{2} \mathrm{Te}_{3}\right)$ saturable absorber in an all-fiber laser ring cavity. As a result, Q-switched pulses in 1- $\mu \mathrm{m}$ wavelength region using ytterbium-doped gain medium were generated. The optical deposition technique was used to fabricate bismuth telluride-based saturable absorber on a fiber ferrule. Using the fabricated SA, Q-switched pulses were generated with repetition rates ranging from 17 to $29.63 \mathrm{kHz}$ at the variation of pump power levels between $88.6 \mathrm{~mW}$ to $111.3 \mathrm{~mW}$. The minimum pulse duration and the maximum pulse energy were measured as $14.54 \mu \mathrm{s}$ and $3.37 \mathrm{~nJ}$, respectively. With an SNR of $42 \mathrm{~dB}$, the results demonstrated that the proposed setup performs stable operation at room temperature. The pulsed laser used simple fiber configuration and is a low cost setup. We believe the results presented in this paper will pave the way and encourage further progress in one micron laser development for near future photonics applications.

\section{ACKNOWLEDGEMENTS}

The authors would like to thank Universiti Kebangsaan Malaysia for research funding under grant number GGPM2017-091.

\section{REFERENCES}

Ahmad, H., Rashid, F.A.A., Azzuhri, S.R., Salim, M.A.M., Shaharuddin, R.A., Ismail, M.A. \& Razak, M.Z.A. 2016. The generation of passive dual wavelengths Q-switched YDFL by $\mathrm{MoSe}_{2}$ film. Laser Physics Letters 13: 11 .

Ahmad, H., Salim, M.A.M., Azzuhri, S.R., Soltanian, M. \& Harun, S.W. 2015. A passively Q-switched ytterbium-doped fiber laser based on a few-layer $\mathrm{Bi}_{2} \mathrm{Se}_{3}$ saturable absorber. Laser Physics 25(6): 065102.

Ahmad, H., Muhammad, F.D., Zulkifli, M.Z. \& Harun, S.W. 2012. Graphene-oxide-based saturable absorber for all-fiber q-switching with a simple optical deposition technique. IEEE Photonics Journal 4(6): 2205-2213.

Bao, Q., Zhang, H., Wang, Y., Ni, Z., Yan, Y. \& Shen, Z.X. 2009. Atomic-layer graphene as a saturable absorber for ultrafast pulsed lasers. Advanced Functional Materials 19(19): 30773083.

Bernard, F., Zhang, H., Gorza, S.P. \& Emplit, P. 2012. Towards mode-locked fiber laser using topological insulators. Nonlinear Photonics 2012: NTh1A. 5.

Chen, Y., Zhao, C., Chen, S., Du, J., Tang, P. \& Jiang, G. 2014. Large energy, wavelength widely tunable, topological insulator Q-switched erbium-doped fiber laser. IEEE Journal of Selected Topics in Quantum Electronics 20(5): 315-322.

Chen, Y., Analytis, J., Chu, J.H., Liu, Z., Mo, S.K. \& Qi, X.L. 2009. Experimental realization of a three-dimensional topological insulator, $\mathrm{Bi}_{2} \mathrm{Te}_{3}$. Science 325(5937): 178-181.

Gao, P., Huang, H., Wang, X., Liu, H., Huang, J., Weng, W., Dai, S., Li, J. \& Lin, W. 2018. Passively Q-switched solidstate Tm: YAG laser using topological insulator $\mathrm{Bi}_{2} \mathrm{Te}_{3}$ as a saturable absorber. Applied Optics 57(9): 2020-2024.

Harun, H.A., Zainal, R. \& Daud, Y.M. 2017. Analisis komposisi kuku manusia menggunakan spektroskopi pemecahan teraruh laser. Sains Malaysiana 46(1): 75-82.

Herda, R., Kivistö, S. \& Okhotnikov, O.G. 2008. Dynamic gain induced pulse shortening in Q-switched lasers. Optics Letters 33(9): 1011-1013.

Kashiwagi, K., Yamashita, S. \& Set, S.Y. 2009. In situ monitoring of optical deposition of carbon nanotubes onto fiber end. Optics Express 17(7): 5711-5715.

Keller, U., Weingarten, K.J., Kärtner, F.X., Kopf, D., Braun, B. \& Jung, I.D. 1996. Semiconductor saturable absorber mirrors 
(SESAM's) for femtosecond to nanosecond pulse generation in solid-state lasers. IEEE Journal of Selected Topics in Quantum Electronics 2(3): 435-453.

Lee, J., Koo, J., Chi, C. \& Lee, J.H. 2014. All-fiberized, passively Q-switched 1.06-um laser using a bulk-structured $\mathrm{Bi}_{2} \mathrm{Te}_{3}$ topological insulator. Journal of Optics 16(8): 085203.

Li, P., Zhang, G., Zhang, H., Zhao, C., Chi, J. \& Zhao, Z. 2014. Switched mode-locked Nd: YVO 4 laser by topological insulator $\mathrm{Bi}_{2} \mathrm{Te}_{3}$ saturable absorber. IEEE Photonics Technology Letters 26(19): 1912-1915.

Lin, Y.Y., Song, W.H., Lee, P., Wang, Y.R., Zhang, H. \& Lee, C.K. 2018. Dynamic cavity effects in topological insulator Bi2Te3 based passive Q-switched solid state laser. Journal of Physics Communications 2(12): 125007.

Liu, J., Wu, S., Yang, Q.H. \& Wang, P. 2011. Stable nanosecond pulse generation from a graphene-based passively Q-switched Yb-doped fiber laser. Optics Letters 36(20): 4008-4010.

Luo, Z.C., Cao, W.J., Luo, A.P. \& Xu, W.C. 2012. Optical deposition of graphene saturable absorber integrated in a fiber laser using a slot collimator for passive mode-locking. Applied Physics Express 5(5): 055103.

Luo, Z.Q., Huang, Y.Z., Weng, J., Cheng, H.H., Lin, Z.Q. \& Xu, B. 2013. $1.06 \mu \mathrm{m}$ Q-switched ytterbium-doped fiber laser using few-layer topological insulator $\mathrm{Bi} 2 \mathrm{Se} 3$ as a saturable absorber. Optics Express 21(24): 29516-29522.

Mohamed, M.A., Zulkefli, F.D. \& Majlis, B.Y. 2017. Pencirian transistor karbon tiub nano berdinding tunggal yang dihasilkan melalui kaedah pertumbuhan langsung. Sains Malaysiana 46(7): 1141-1145.

Martinez, A., Fuse, K., Xu, B. \& Yamashita, S. 2010. Optical deposition of graphene and carbon nanotubes in a fiber ferrule for passive mode-locked lasing. Optics Express 18(22): 23054-23061.

Pinghua, T., Xiaoqi, Z., Chujun, Z., Yong, W., Han, Z. \& Deyuan, S. 2013. Topological insulator: $\left(B i_{2} \mathrm{Te}_{3}\right)$ Saturable absorber for the passive Q-switching operation of an in-band pumped 1645-nm Er:YAG ceramic laser. IEEE Photonics Journal 5(2): 1500707-1500707.

Razak, M., Anyi, C., Saleh, Z.S., Ahmad, F., Harun, S.W. \& Arof, H. 2016. High-power Q-switched erbium-ytterbium codoped fiber laser using multiwalled carbon nanotubes saturable absorber. Journal of Optical Engineering 55(10): 106112.

Russo, V., Bailini, A., Zamboni, M., Passoni, M., Conti, C., Casari, C.S., Bassi, A.L. \& Bottani, C.E. 2008. Raman spectroscopy of Bi-Te thin films. Journal of Raman Spectroscopy 39(2): 205-210.

Salim, M.A.M., Ahmad, H., Harun, S.W., Bidin, N. \& Krishnan, G. 2018. Generation of an ultrafast femtosecond soliton fiber laser by carbon nanotube as saturable absorber. Journal of Physics: Conference Series 1027(1): 012011.

Salim, M.A.M., Shaharuddin, R., Ismail, M., Harun, S.W., Ahmad, H. \& Azzuhri, S.R. 2017. $\mathrm{Bi}_{2} \mathrm{Te}_{3}$ based passively Q-switched at 1042.76 and $1047 \mathrm{~nm}$ wavelength. Laser Physics 27(12): 125102.

Sun, Y.J., Lee, C.K., Xu, J.L., Zhu, Z.J., Wang, Y.Q. \& Gao, S.F. 2015. Passively Q-switched tri-wavelength $\mathrm{Yb}^{3+}: \mathrm{GdAl}_{3}\left(\mathrm{BO}_{3}\right)_{4}$ solid-state laser with topological insulator $\mathrm{Bi}_{2} \mathrm{Te}_{3}$ as saturable absorber. Photonics Research 3(3): A97-A101.

Yang, J., Tian, K., Li, Y., Dou, X., Ma, Y., Han, W., Xu, H. \& Liu, J. 2018. Few-layer Bi 2 Te 3: An effective 2D saturable absorber for passive Q-switching of compact solid-state lasers in the 1- $\mu \mathrm{m}$ region. Optics Express 26(17): 21379-21389.
Zayhowski, J. \& Kelley, P. 1991. Optimization of Q-switched lasers. IEEE Journal of Quantum Electronics 27(9): 22202225 .

Zhang, H., Liu, C.X., Qi, X.L., Dai, X., Fang, Z. \& Zhang, S.C. 2009. Topological insulators in $\mathrm{Bi} 2 \mathrm{Se} 3, \mathrm{Bi} 2 \mathrm{Te} 3$ and $\mathrm{Sb} 2 \mathrm{Te} 3$ with a single Dirac cone on the surface. Nature Physics 5(6): 438-442.

Zhang, L., Fan, J., Wang, J., Hu, J., Lotya, M. \& Wang, G. 2012. Graphene incorporated Q-switching of a polarizationmaintaining Yb-doped fiber laser. Laser Physics Letters 9(12): 888

Zhao, C., Zou, Y., Chen, Y., Wang, Z., Lu, S. \& Zhang, H. 2012. Wavelength-tunable picosecond soliton fiber laser with topological insulator: $\mathrm{Bi}_{2} \mathrm{Se}_{3}$ as a mode locker. Optics Express 20(25): 27888-27895.

Zitter, R.N. 1969. Saturated optical absorption through band filling in semiconductors. Applied Physics Letters 14(2): 73-74.

Muhammad Aizi Mat Salim

Laser Center

Ibnu Sina Institute for Scientific and Industrial Research (ISI-SIR)

Universiti Teknologi Malaysia

81310 Johor Bahru, Johor Darul Takzim

Malaysia

Mohd Zulhakimi Ab Razak*

Institute of Microengineering and Nanoelectronics (IMEN)

Universiti Kebangsaan Malaysia

43600 UKM Bangi, Selangor Darul Ehsan

Malaysia

Saaidal Razalli Azzuhri

Department of Computer Systems and Technology

Faculty of Computer Science and Information Technology

University of Malaya

50603 Kuala Lumpur Federal Territory

Malaysia

Mohd Afiq Ismail \& Fauzan Ahmad

Malaysia-Japan International Institute of Technology (MJIIT)

Universiti Teknologi Malaysia

54100 Kuala Lumpur, Federal Territory

Malaysia

Sulaiman Wadi Harun

Department of Electrical Engineering

Faculty of Engineering

University of Malaya

50603 Kuala Lumpur, Federal Territory

Malaysia

*Corresponding author; email: zul.hakimi@ukm.edu.my

Received: 2 January 2019

Accepted: 28 February 2019 